LMEC-Memo-72-2

Limited Distribution

cenont

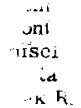

rmat:

\title{
Feasibility of Weld-Repairing Hardware Containing Solid Sodium
}

\author{
By \\ E. G. Thompson
}

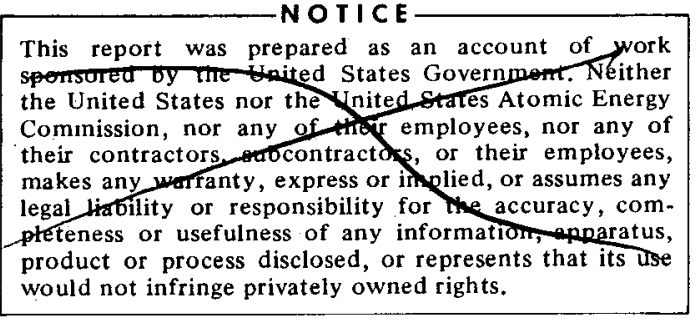

This documete is

PUURLICEY RELEASABLE

Authorizing Official

Dater

\section{Liquid Metal Engineering Center

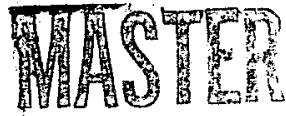

\section{Operated for}

the U.S. Atomic Energy Commission by Atomics International

\author{
A Division of North American Rockwell Corporation
}

Gntract: AT(04-3)-700

Issued: January 25, 1972
Released For Annouricement If Aluctear Seiencd Lhatran:- Oistribution Limited i) Partivipaits in the 4 LEBR Program. Uthers request from $\mathrm{JIC}_{\text {. }}$

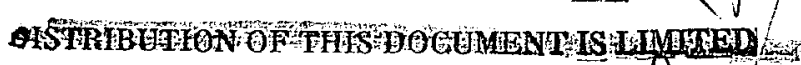

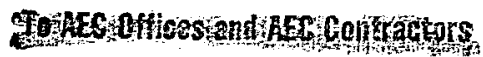




\section{DISCLAIMER}

This report was prepared as an account of work sponsored by an agency of the United States Government. Neither the United States Government nor any agency Thereof, nor any of their employees, makes any warranty, express or implied, or assumes any legal liability or responsibility for the accuracy, completeness, or usefulness of any information, apparatus, product, or process disclosed, or represents that its use would not infringe privately owned rights. Reference herein to any specific commercial product, process, or service by trade name, trademark, manufacturer, or otherwise does not necessarily constitute or imply its endorsement, recommendation, or favoring by the United States Government or any agency thereof. The views and opinions of authors expressed herein do not necessarily state or reflect those of the United States Government or any agency thereof. 


\section{DISCLAIMER}

Portions of this document may be illegible in electronic image products. Images are produced from the best available original document. 


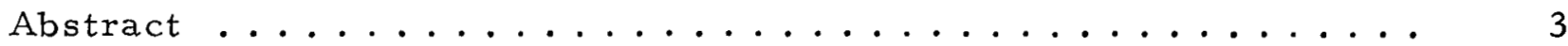

I. Introduction ......................... 4

II. Experimental Test Procedure and Hardware ........... 5

III. Experimental Results and Conclusions.............. 5

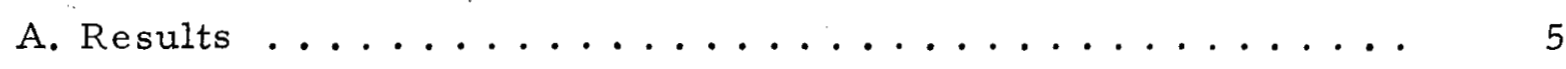

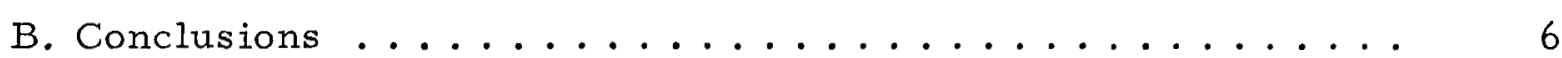

IV. Discussion of Results and Applications .............. 6

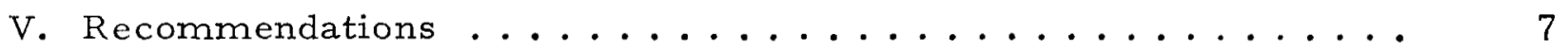

TABLE

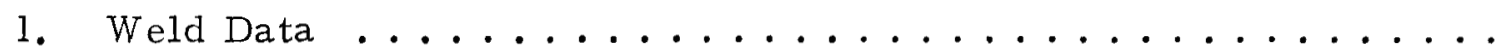

\section{FIGURES}

1. Sketch of Defective Pipe-to-Tank Fillet Weld (SCTI Primary Fill and Drain Tank) .............. 9

2. Experimental Test Specimen .................. 10

3. Machined Grooves in External Face of Plate for Simulated

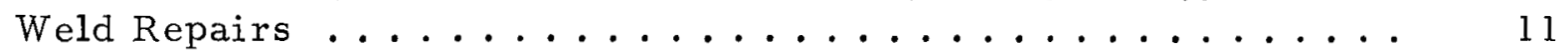

4. Experimental Setup for Evaluation of Weld Repair of Sodium-

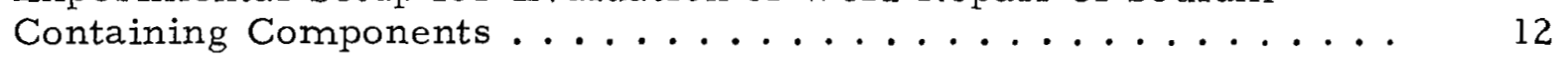

5. Simulated Defects After Repair Welding ............. 12

6. Schematic Representation of Weld Defects Repaired on SCTI

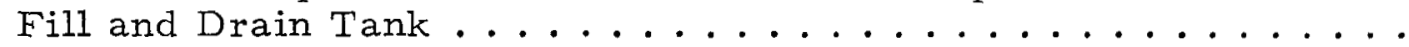




\section{ABSTRACT}

An experiment is reported which demonstrated the feasibility of making weld repairs of weld or parent metal defects in components containing solid sodium. Application of the information derived to the successful repair of fillet welds in tanks containing solid sodium is described. 


\section{INTRODUCTION}

Initial liquid penetrant inspection of the drain line (line 601-2-p) pipe-totank external fillet weld on the SCTI Primary Fill and Drain Tank revealed numerous unacceptable linear and rounded indications. However, after the rough-surfaced, shielded metal-arc weld was ground smooth and reinspected, many unacceptable indications were eliminated. Further general surface grinding and reinspection eliminated all unacceptable indications except for five slag inclusions at the toe of the fillet weld on the tank. Removal of these defects by localized grinding was initiated. The largest defect required grinding to a depth of $0.30 \mathrm{in}$. Weld repair of the areas thinned by grinding was required.

The weld in question joined a 2 -in. Schedule 40, SA-312 Type 304 seamless stainless steel pipe to an SA-212, Grade B (70,000-psi), dished tank head. A schematic of the joint is shown in Figure 1.

The thickness of the tank head was checked with ultrasonic instrumentation and determined to be $0.605 \pm 0.005$ in. Weld metal and pipe metal filings were obtained and analyzed. The pipe material was confirmed as Type 304 stainless steel. The weld metal was identified as follows (in wt \%):

$\begin{array}{ll}31 & \mathrm{Ni} \\ 30 & \mathrm{Cr} \\ 2-3 & \mathrm{Mn} \\ 0 & \mathrm{Cb}, \mathrm{Mo}, \mathrm{Ti} \\ \text { Balance } & \mathrm{Fe}\end{array}$

The unusual weld metal analysis was reconfirmed on a second sample. The actual filler metal used could not be determined, but the composition approximated Incoloy 135, a coated nickel-base alloy electrode.

The 7500-gal tank contains approximately 6000 gal of solid sodium. Since the facility does not have sufficient storage capacity to permit draining this tank, the feasibility of making weld repairs with the sodium "in situ" was considered.

LMEC-Memo-72-2 
A heat transfer analysis indicated that melting and possibly volatalization of the sodium would occur at the inner wall of the tank during welding, accompanied by pressure effects. The analysis was based on an estimated maximum weld energy input and other assumptions. The validity of the assumptions was considered sufficiently questionable to conduct a verification welding experiment.

\section{EXPERIMENTAL TEST PROCEDURE AND HARDWARE}

The test specimen shown in Figure 2 was designed and fabricated for the welding experiment. It consisted of a 6-in. Schedule 40, carbon steel pipe that was fillet-welded to a 0.440-in.-thick, 7-in.-square, carbon steel plate. The plate represented the dished head of the tank. Its thickness was based on engineering drawings which called out a nominal tank wall thickness of $7 / 16$ in. (As noted and subsequent to this experiment, ultrasonic measurements established the dished head thickness in the vicinity of the weld as actually $0.605 \pm$ 0.005 in.) Several grooves machined in the external face of the plate simulated grindouts requiring weld repairs. These are shown in Figures 2 and 3 . Two stainless-steel-sheathed thermocouples were welded to the backface of the plate in the locations indicated and connected to instrumentation to provide rapid readout of temperature during welding. Sodium was then cast in the pipe to a depth of about $10 \mathrm{in.}$

The experimental setup for welding is shown in Figure 4. The manual gas tungsten-arc process was used with Type ER 308 filler wire. The plate with all simulated defects repair-welded is shown in Figure 5.

\section{EXPERIMENTAL RESULTS AND CONCLUSIONS}

\section{A. RESULTS}

Table 1 presents the data obtained from welding of the simulated grindouts. Groove 1 established that by restricting the arc time to 4 to 5 -sec increments, the backface peak temperature could be held to about $210^{\circ} \mathrm{F}$, thereby accomplishing welding without melting of the sodium. This increment of arc time was just sufficient to obtain a molten weld puddle and melt off a short (approximately 1/8-in.) length of filler metal. Further tests reported in Table 1

$$
\text { LMEC-Memo-72-2 }
$$


established that welding could be successfully accomplished even though sodium against the backface of the plate was melted. In the final test, welding of the root pass of groove 2 (5-3/8 in. long) was accomplished in two sequences of about 50-sec arc time each with a 30-sec cooling time in between. The maximum temperature attained approached $300^{\circ} \mathrm{F}$ at TC4 (1-1/8 in.away from the groove centerline). The second weld pass was made in a single sequence with an arc time of $195 \mathrm{sec}$. In spite of the increased arc time, the maximum temperature measured was lower than for the first pass.

\section{B. CONCLUSIONS}

The experiment proved that weld repair of defects in mild steel components containing solid sodium was practical, provided that the wall thickness remaining between the bottom of the weld grindout and the sodium was at least $0.190 \mathrm{in}$. Peak temperatures measured during welding established that the first pass was the most critical operation.

Repair was possible without melting any sodium. However, repair was also successfully and more practically accomplished by permitting localized melting of the sodium.

\section{DISCUSSION OF RESULTS AND APPLICATIONS}

Weld repair of the defective pipe-to-tank fillet weld in the drain line (line 601-2-p) of SCTI T-1 Fill and Drain Tank was accomplished using a special qualified weld repair procedure for this Type 304 stainless steel-to-mild steel fillet weld joint. In accordance with this procedure, RDT M 1-2T, Class ERNiCr-3 (Inconel 82) filler metal was used to repair the five grindouts depicted schematically in Figure 6, using the multi-pass weld technique. The deepest grindout was about $0.30 \mathrm{in}$., which reduced the tank wall thickness to $0.30 \mathrm{in}$. This thickness is considerably greater than the $0.190-\mathrm{in}$. minimum used for the experimental weld test. This grindout also penetrated close to the OD of the 2 -in. Schedule 40 , Type 304 stainless steel pipe. The remaining wall thickness on the pipe side of the joint was estimated at not less than the 0.154-in. nominal wall thickness of this pipe and not more than 0.190 in. No problems were encountered during welding and all repairs were acceptable as

LMEC-Memo-72-2 
determined by liquid penetrant inspection of each completed weld repair in accordance with RDT F 3-6T.

Repair of the saddle-to-tank, cracked fillet welds on LCTL Supply Tank T-2 and Drain Tank T-3 was also accomplished with solid sodium in the tanks. In both cases, the tank shells and the saddles were fabricated from 5/8-inthick, Type 304 stainless steel plate. The cracks were continuous for several inches a round the ends of the saddles. Depths of grindouts below the tank wall surface did not exceed 3/16 in., leaving a wall thickness of about 7/16 in. Welding was accomplished in accordance with RDT E 15-2T using a qualified weld procedure for Type P8-to-P8 material and ER 308 filler wire. No problems were encountered during welding and all repairs were acceptable as determined by liquid penetrant inspection of each completed weld repair in accordance with RDT F 3-6T.

\section{RECOMMENDATIONS}

Experience gained to date on the experimental test hardware and on the successful applications, the latter involving vessels containing massive quantities of solid sodium, have shown that weld repairs of either carbon steel or austenitic stainless steel components containing solid sodium are practical. Successful weld repair is dependent on two factors: (1) the remaining wall thickness separating the sodium and the welding arc after removal of a defect and (2) the volume of sodium available as a cooling medium in the immediate vicinity of the repair. The former is considered the most important factor. The importance of the latter can only be established by experience. It is therefore recommended that in all cases where weld repair of a component containing solid sodium is under consideration, a welding engineer be consulted for direction. 
TABLE 1

WELD DATA

\begin{tabular}{|c|c|c|c|}
\hline Groove & Weld Pass & $\begin{array}{l}\text { Arc Time } \\
\text { (s ec) }\end{array}$ & $\begin{array}{c}\text { Maximum Backface } \\
\text { Temperature } \\
\left({ }^{\circ} \mathrm{F}\right)\end{array}$ \\
\hline 1 & Root and second & $\begin{array}{l}4 \text { to } 5 \mathrm{sec} \\
\text { intervals }\end{array}$ & 200 to 210 \\
\hline \multirow[t]{3}{*}{2} & Root (first half) & 105 & $214(\mathrm{TCl})$ \\
\hline & Root (last half) $\int$ & & $290(\mathrm{TC} 4)$ \\
\hline & Second & 195 & $280(\mathrm{TC} 4)$ \\
\hline \multirow[t]{2}{*}{3} & Root & 35 & - \\
\hline & Second & 48 & - \\
\hline \multirow[t]{3}{*}{4} & Root & 34 & 313 \\
\hline & Second & 20 & 263 \\
\hline & Third & 27 & 248 \\
\hline 5 & $\begin{array}{l}\text { Root and second } \\
\text { (continuous) }\end{array}$ & 75 & - \\
\hline
\end{tabular}

LMEC-Memo-7-2 


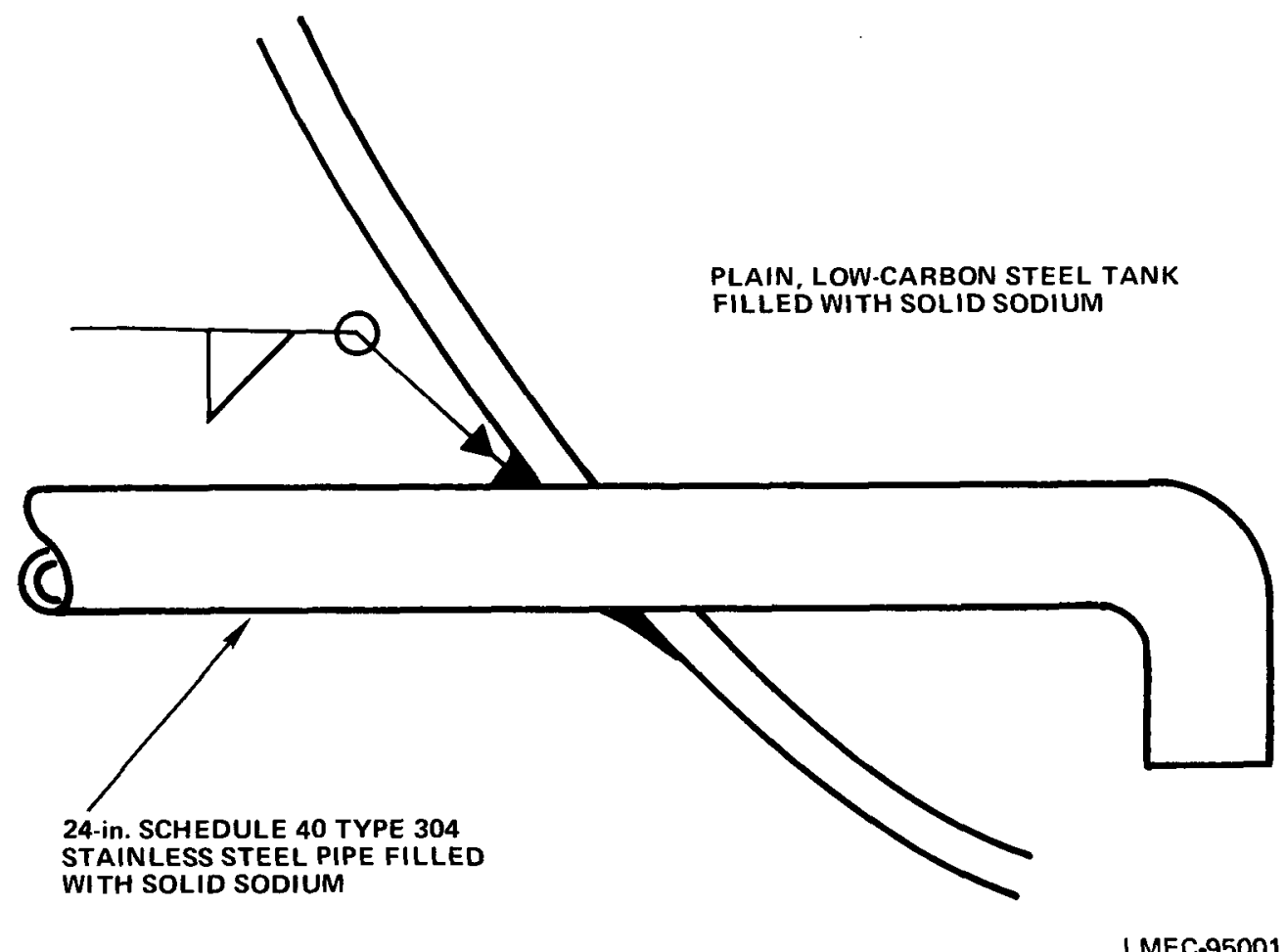

Figure 1. Sketch of Defective Pipe-to-Tank Fillet Weld (SCTI Primary Fill and Drain Tank)

LMEC-Memo-7-2 


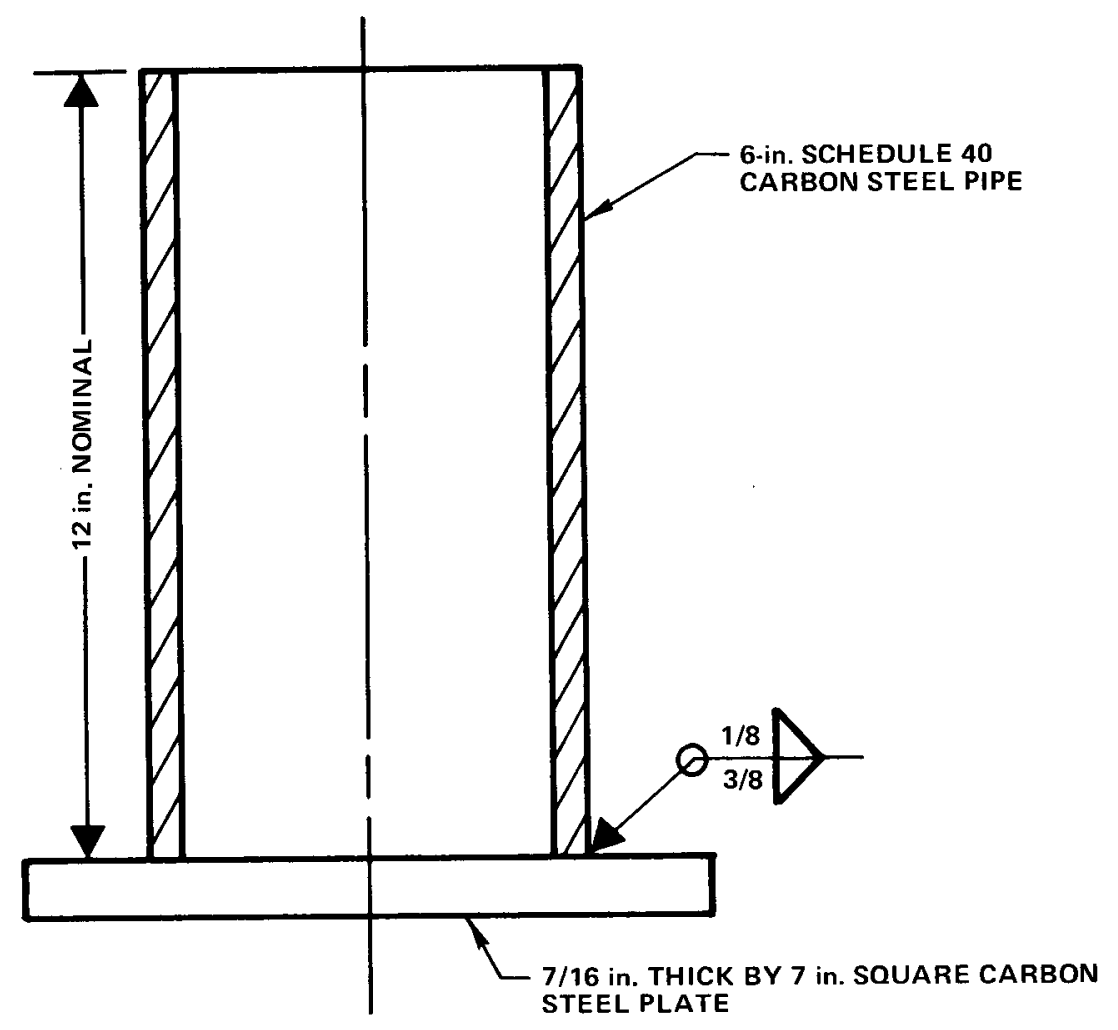

GROOVE DETAIL

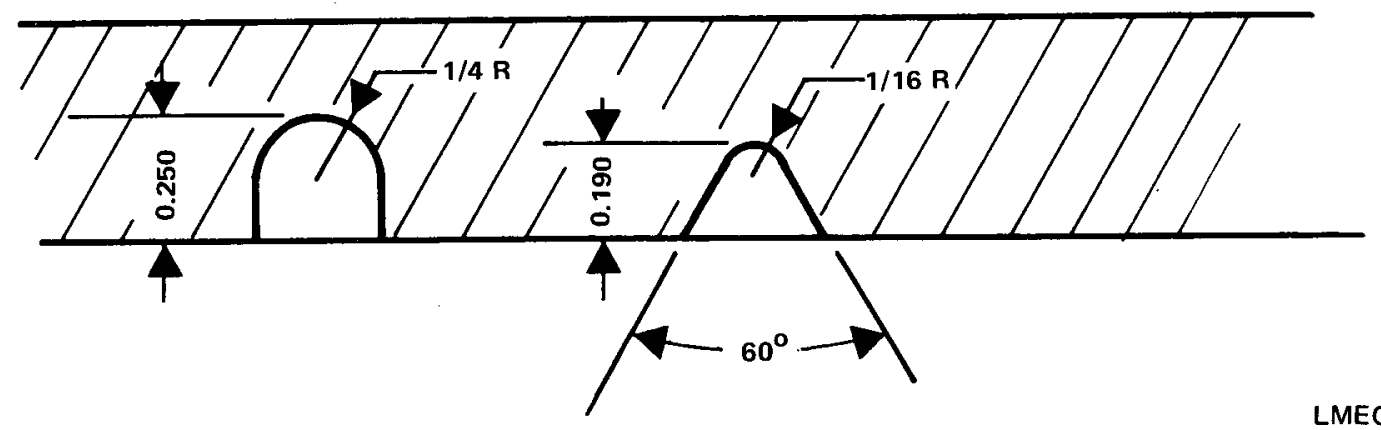

LMEC-95002

Figure 2. Experimental Test Specimen

LMEC-Memo-7-2 


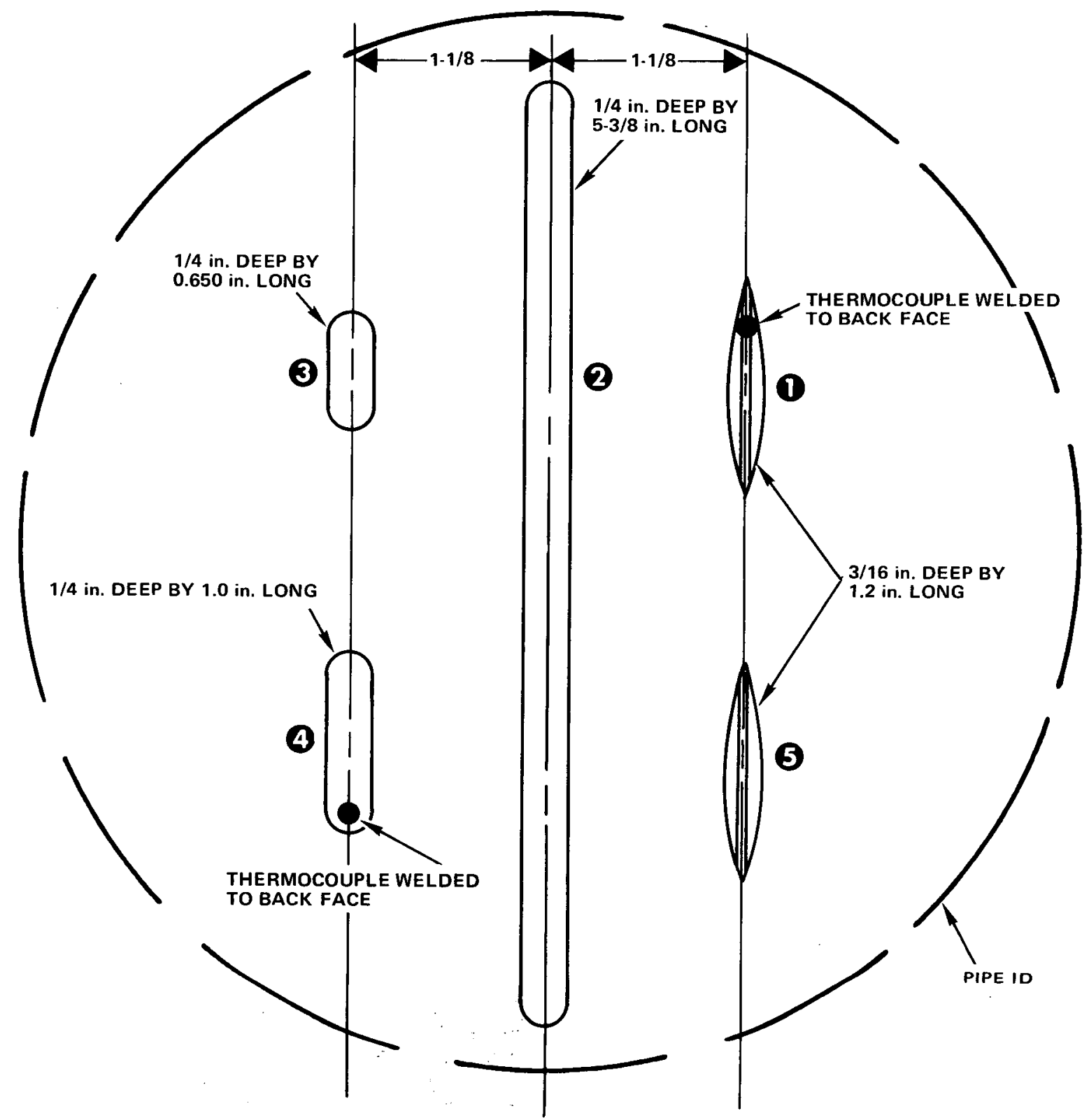

7 in. SQUARE

LMEC.95003

Figure 3. Machined Grooves in External Face of Plate for Simulated Weld Repairs

LMEC-Memo-7-2 


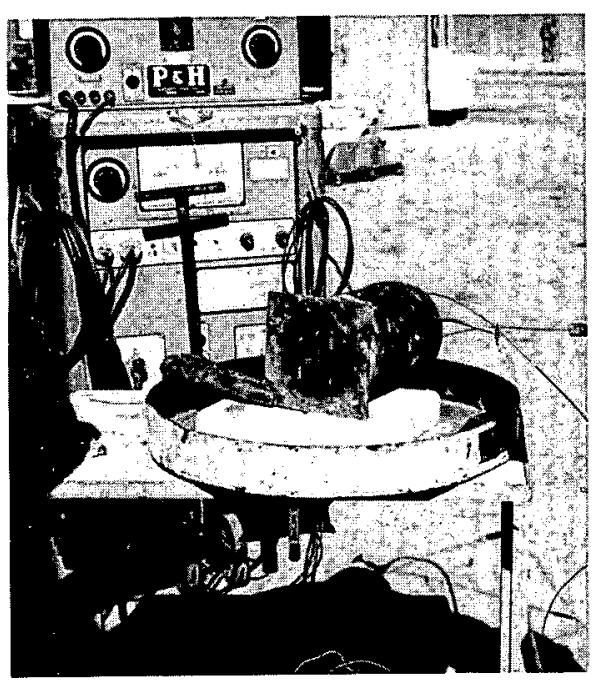

LMEC-P95004
Figure 4. Experimental Setup for Evaluation of Weld Repair of Sodium-Containing Components
Figure 5. Simulated Defects After Repair Welding

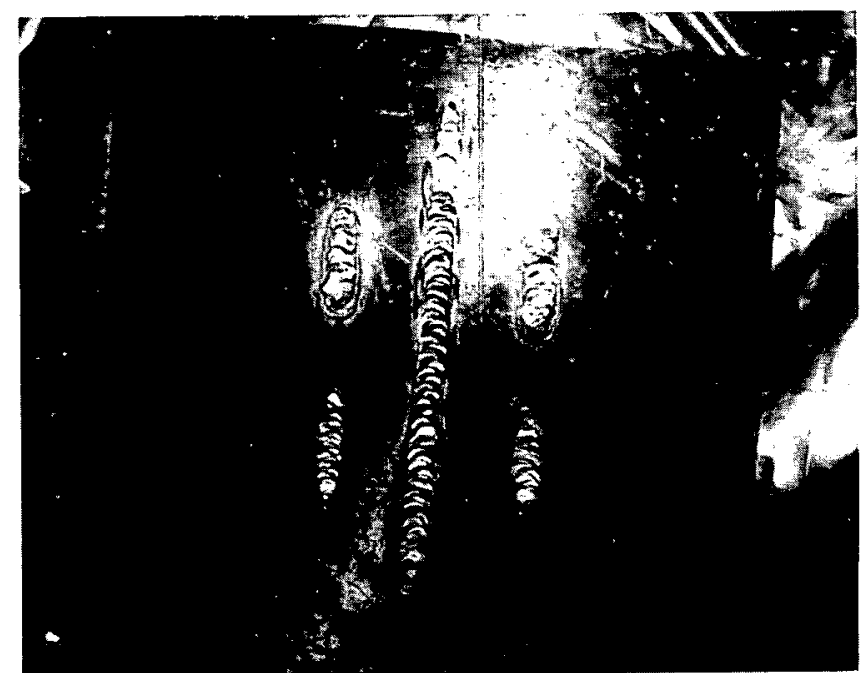

LMEC-P95005 


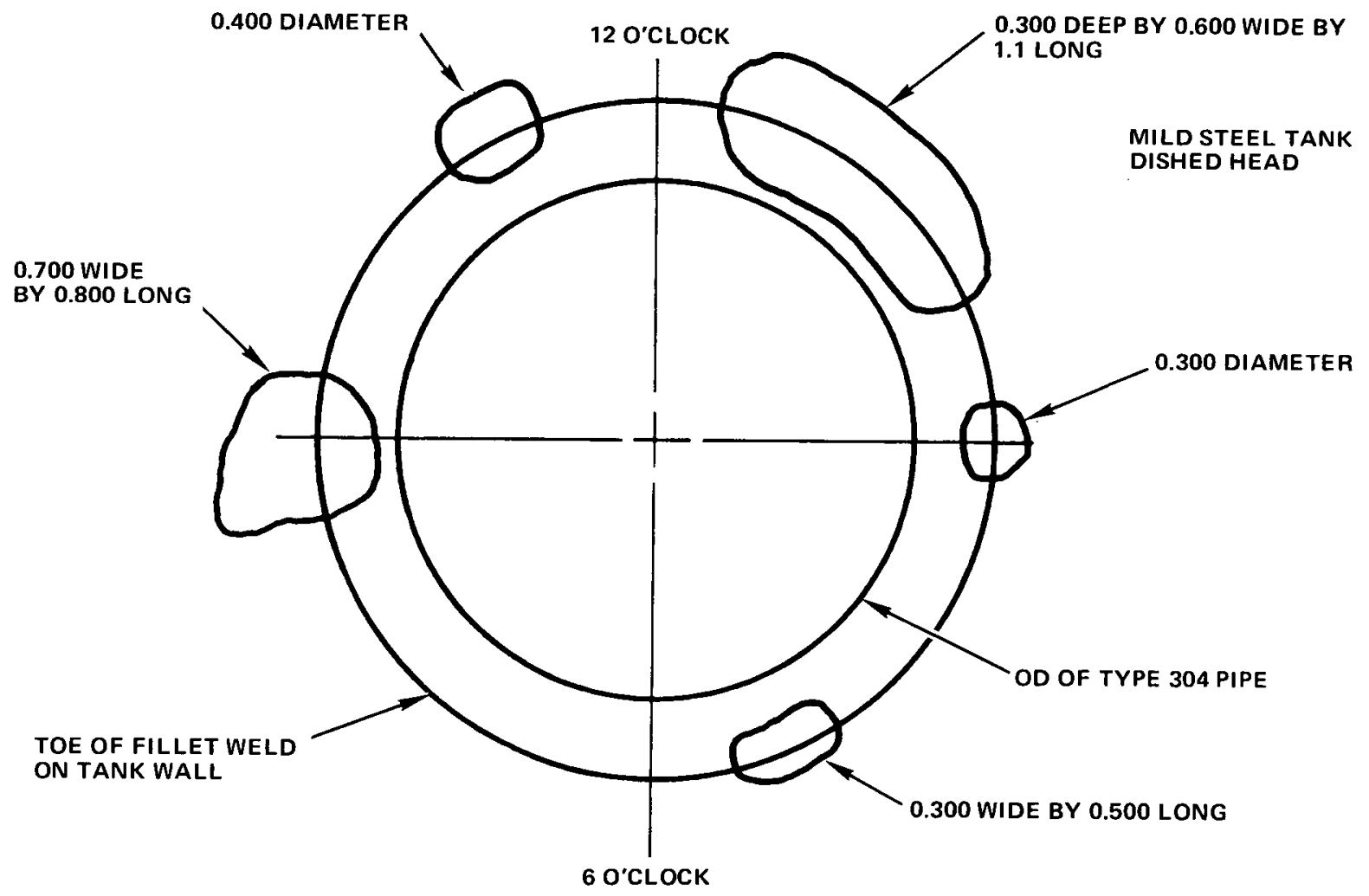

NOTE: DIMENSIONS (IN INCHES) OF GRINDOUTS ARE FROM ROUGH MEASUREMENTS

Figure 6. Schematic Representation of Weld Defects Repaired on SCTI Fill and Drain Tank 